\title{
Prevalence and Ecological Association of Foliar Pathogens of Cucumber in North Carolina, 1996-1998
}

\author{
P. D. Peterson and C. L. Campbell, Department of Plant Pathology, North Carolina State University, Raleigh \\ 27695
}

\begin{abstract}
Peterson, P. D., and Campbell, C. L. 2002. Prevalence and ecological association of foliar pathogens of cucumber in North Carolina, 1996-1998. Plant Dis. 86:1094-1100.

During the fall growing seasons of 1996-98, 5,400 leaves exhibiting leaf spots were collected from cucumber (Cucumis sativus L.) fields and microscopically examined to identify the organisms associated with these symptoms. Five fungal pathogens were associated with leaf lesions: Alternaria cucumerina, Colletotrichum orbiculare, Corynespora cassiicola, Didymella bryoniae, and Pseudoperonospora cubensis; D. bryoniae and C. orbiculare occurred most frequently. When pathogens were paired on five or more leaves, associations between pathogen pairs were tested for independence via a 2-by-2 contingency table $\chi^{2}$ analysis. In all, 66 twoway pathogen associations were tested. Of these, 39 associations were negative (occurred together less often than expected at random), 1 was positive (occurred together more often than expected at random), and, in 16 cases, the pathogens were not associated. An association between $C$. orbiculare and D. bryoniae occurred 24 times and, each time, the relationship was negative. This result, combined with different environmental requirements for infection, suggests that these pathogens either occupy different niches in the plant canopy or are antagonistic. No relationship between the cultivars grown or the fungicides applied and the pathogens isolated from specific field sites was found. Information on the dominant pathogens responsible for leaf spot epidemics in North Carolina's cucumber fields will be useful to target breeding and disease control strategies.
\end{abstract}

North Carolina ranks second nationally in production of pickling or processing cucumbers (Cucumis sativus L.) and is among the top-ranked producers of fresh market cucumbers. Cucumber acreage is centered in the Coastal Plain of the state, where growers plant two crops annually; the first is harvested during June and July and the second between August and October.

Foliar fungal diseases can reduce yields in cucumber production $(1,13,16)$. Necrotic lesions and loss of tissue decrease the productive leaf area and expose the fruit, leading to sunburn. Management practices such as the use of clean seed, crop rotation, fungicide sprays, and resistant cultivars reduce losses due to foliar pathogens, but severe epidemics still may develop when conditions favor pathogen growth and reproduction $(4,7,9,15,16)$.

In North Carolina, inoculum production builds up during the first cucumber crop, resulting in increased incidence and severity of leaf spot diseases during the fall cucumber crop. More intensive management practices, mainly in the form of ear-

Corresponding author: P. D. Peterson

E-mail: paul_peterson@ncsu.edu

Accepted for publication 16 May 2002.

Publication no. D-2002-0724-01R

(C) 2002 The American Phytopathological Society lier and more frequent applications of fungicides such as chlorothalonil, mancozeb, and benomyl, are necessary to manage these leaf spotting pathogens during the fall cucumber crop $(4,16-18)$. Not all cucumber leaf spot diseases can be effectively controlled by labeled fungicides (1).

No information is available in the literature concerning the prevalence or time of occurrence of the spectrum of fungi causing leaf spots on cucumber in the southeastern United States. Furthermore, no information is available regarding how frequently these pathogens co-infect leaves. Not every fungicide or cultural management method is expected to be equally effective against each of the pathogens; therefore, a better understanding of aspects of their biology would improve the management of cucumber leaf spot diseases. The objectives of this study were to (i) determine the spectrum and prevalence of foliar pathogens on cucumber leaves and (ii) determine if there are ecological associations among these pathogens, specifically the impact of one organism on the presence of another.

\section{MATERIALS AND METHODS}

Sample collection. Leaves exhibiting leaf spot symptoms were collected during September and October in 1996, 1997, and 1998 from cucumber fields in the southern Coastal Plain of North Carolina. Cultivar planted, cultivation practices, and chemical controls used in the fields from which the samples were collected were recorded in 1997 and 1998 (Table 1). One set of 200 leaves was collected from each of six different fields throughout Edgecombe, Pitt, and Sampson counties in 1996. One set of 100 leaves was collected from each of 18 different fields throughout Columbus, Duplin, Edgecombe, Lenoir, Sampson, and Wayne counties in 1997. One set of 100 leaves was collected from each of 24 different fields throughout Duplin, Edgecombe, Greene, Lenoir, Nash, Roberson, Wayne, and Wilson counties in 1998. Leaves were collected arbitrarily within the plant canopy and represented all stages of leaf development. Each set of leaves was collected from four within-row linear transects of $25 \mathrm{~m}$ (50 m in 1996), with all transects arranged in a diamond-shaped pattern within each field. Five leaves exhibiting discrete leaf spots were arbitrarily selected at 5-m intervals along the transect, providing 25 leaves per transect (50 in 1996) and 100 leaves per set (200 in 1996). Leaves were placed in plastic bags in a cooler and transported to the laboratory, where they were refrigerated until pathogen identification was completed in less than 5 days.

Lesions on leaves were viewed through a stereoscope at $\times 20$ to $\times 70$, and specific morphological characteristics or signs of sporulating pathogens were used for identification. The presence or absence of each pathogen on each leaf was recorded. When two pathogens occurred together on a single leaf more than five times per set of leaves, associations among the pathogens were compared. For each pair of pathogen species, the following were calculated: $a=$ number of leaves where both species occurred, $b=$ number of leaves where only species $X$ occurred, $c=$ number of leaves where only species $Y$ occurred, $d=$ number of leaves where neither species was identified, and $N=$ total number of leaves collected. The null hypothesis of no association (i.e., independence) was tested by computing the $\chi^{2}$ statistic (12):

$\chi^{2}=N(a d-b c)^{2} / m n r s$

(eq. 1)

where $m=a+b, n=c+d, r=a+c$, and $s$ $=b+d$ and the theoretical $\chi^{2}$ value for 1 degree of freedom at the $5 \%$ probability level is 3.84. Pathogen associations were classified as positive or negative. A positive association indicated that the pair of species occurred together more often than expected at random. A positive association 
may result from the presence of one member of the pathogen pair promoting the growth of the other, where the two pathogens do not exploit overlapping niches. A negative association indicated that the pair of species occurred together less often than expected at random. A negative association may result from the competition between two pathogens requiring the same resources and occupying the same ecological niche or from the two pathogens occupying different ecological niches.

Another component of the relationship between two species is the strength of the association (11). Nelson and Campbell (10) used the Ochiai index (OI) as a measure of the strength of association between pathogen pairs in the leaf spot pathosystem in white clover. The OI measures the ratio of the number of joint occurrences of two pathogens to the total occurrences of each of the pathogens separately. This index ranges from 0 , indicating "no association" between the pathogens, to 1, indicating "maximum association" (11):

$\mathrm{OI}=a /\left[(a+b)^{1 / 2}(a+c)^{1 / 2}\right]$

where $a, b$, and $c$ are defined as before.

\section{RESULTS}

Spectrum and prevalence. Leaf spot diseases during the second cucumber growing cycle in North Carolina were caused primarily by five fungal pathogens: Alternaria cucumerina (Ellis \& Everh.) J. A. Elliott, causal organism of Alternaria leaf blight; Colletotrichum orbiculare (Berk. \& Mont.) Arx, causal organism of anthracnose; Corynespora cassiicola (Berk. \& M. A. Curtis) C. T. Wei, causal organism of target spot; Didymella bryoniae (Auersw.) Rehm, causal organism of gummy stem blight; and Pseudoperonospora cubensis (Berk. \& M. A. Curtis) Rostovzev, causal organism of downy mildew (Fig. 1).
In 1996, disease incidence was high and Colletotrichum orbiculare, Corynespora cassiicola, D. bryoniae, and P. cubensis occurred frequently on leaves. Colletotrichum orbiculare was the most prevalent pathogen, occurring most frequently at three of the six sites (PF1, PF2, and SF2; Fig. 1).

A more diverse array of pathogens, comprising A. cucumerina, Colletotrichum orbiculare, Corynespora cassiicola, D. bryoniae, and $P$. cubensis, occurred frequently on leaves collected during 1997 and 1998 (Figs. 2 and 3). In 1997, disease incidence overall was lower than in 1996 and 1998, and D. bryoniae was the most prevalent pathogen, occurring most frequently at 7 of the 18 field sites (CF3, EF3, SF1, SF2, SF3, WF1, and WF3). Pseudoperonspora cubensis, Corynespora cassiicola and Colletotrichum orbiculare were the most prevalent pathogens at four (CF1, DF1, DF2, and DF3), four (LF1, LF2,

Table 1. Locations and crop histories of North Carolina cucumber field sites from which leaves exhibiting leaf-spot symptoms were collected in 1997 and 1998

\begin{tabular}{|c|c|c|c|c|c|}
\hline Year, county & Site & Fungicide $^{\mathrm{a}}$ & Previous crop & Cultivar & Planting date ${ }^{b}$ \\
\hline \multicolumn{6}{|l|}{1997} \\
\hline \multirow[t]{3}{*}{ Columbus } & CF1 & Met & Cucumber & Jackson & 08/02/97 \\
\hline & CF2 & Met & Cucumber & Vlasstar & 08/09/97 \\
\hline & $\mathrm{CF} 3$ & Met & Cucumber & Vlasstar & 08/13/97 \\
\hline \multirow[t]{3}{*}{ Duplin } & DF1 & Chlor/Ben/Met & Sweet corn & Cross Country & 08/05/97 \\
\hline & DF2 & Chlor/Ben/Met & Bean & Cross Country & 08/10/97 \\
\hline & DF3 & None & Bean & Cross Country & 08/10/97 \\
\hline \multirow[t]{3}{*}{ Edgecombe } & $\mathrm{EF} 1$ & Unknown & Unknown & Unknown & 08/01/97 \\
\hline & EF2 & Unknown & Unknown & Unknown & 08/01/97 \\
\hline & EF3 & Unknown & Unknown & Unknown & 08/01/97 \\
\hline \multirow{3}{*}{ Lenoir } & LF1 & Chlor & Unknown & Cross Country & Unknown \\
\hline & LF2 & Chlor & Unknown & Cross Country & Unknown \\
\hline & LF3 & Chlor & Unknown & Cross Country & Unknown \\
\hline \multirow[t]{3}{*}{ Sampson } & SF1 & Unknown & Unknown & Unknown & Unknown \\
\hline & SF2 & Unknown & Unknown & Unknown & Unknown \\
\hline & SF3 & Unknown & Unknown & Unknown & Unknown \\
\hline \multirow[t]{3}{*}{ Wayne } & WF1 & Unknown & Cucumber & Cross Country & 08/01/97 \\
\hline & WF2 & Unknown & Cucumber & Cross Country & 08/01/97 \\
\hline & WF3 & Unknown & Cucumber & Cross Country & 08/01/97 \\
\hline \multicolumn{6}{|l|}{1998} \\
\hline \multirow[t]{3}{*}{ Duplin } & DF1 & Unknown & Cucumber & Vlasstar & 07/31/98 \\
\hline & DF2 & Unknown & Cucumber & Vlasstar & 08/10/98 \\
\hline & DF3 & Unknown & Cucumber & Vlasstar/Cross Country & 08/13/98 \\
\hline \multirow[t]{3}{*}{ Edgecombe } & EF1 & Chlor & Cucumber & Vlaspik & 08/20/98 \\
\hline & $\mathrm{EF} 2$ & Chlor & Cucumber & Vlaspik & 08/08/98 \\
\hline & EF3 & Chlor & Cucumber & Vlaspik & 07/29/98 \\
\hline \multirow[t]{3}{*}{ Greene } & GF1 & Chlor/Thio & Cucumber & Napolean/Jackson & $07 / 23 / 98$ \\
\hline & GF2 & Chlor & Cucumber & Napolean/Jackson & $07 / 24 / 98$ \\
\hline & GF3 & Chlor & Cucumber & Napolean/Jackson & $07 / 25 / 98$ \\
\hline \multirow[t]{3}{*}{ Lenoir } & LF1 & Chlor & Cucumber & Cross Country & 08/01/98 \\
\hline & LF2 & Chlor & Cucumber & Cross Country & 08/01/98 \\
\hline & LF3 & Chlor & Cucumber & Cross Country & 08/01/98 \\
\hline \multirow[t]{3}{*}{ Nash } & NF1 & Chlor & Cucumber & Vlaspik & 08/20/98 \\
\hline & NF2 & Chlor & Cucumber & Vlaspik & 08/08/98 \\
\hline & NF3 & Ben & Cucumber & Vlaspik & 07/29/98 \\
\hline \multirow[t]{3}{*}{ Roberson } & RF1 & None & Soybean & Vlasstar & $08 / 14 / 98$ \\
\hline & RF2 & None & Soybean & Vlasstar & 08/14/98 \\
\hline & RF3 & None & Soybean & Vlasstar & 08/15/98 \\
\hline \multirow[t]{3}{*}{ Wayne } & $\mathrm{WaF} 1$ & $\mathrm{Mz}$ & Cucumber & Vlasstar & $07 / 31 / 98$ \\
\hline & WaF2 & $\mathrm{Mz}$ & Cucumber & Vlasstar & 07/31/98 \\
\hline & WaF3 & $\mathrm{Mz}$ & Cucumber & Vlasstar & 07/31/98 \\
\hline \multirow[t]{3}{*}{ Wilson } & WF1 & Chlor & Cucumber & Napolean/Jackson/Cross Country & 08/01/98 \\
\hline & WF2 & Chlor & Cucumber & Jackson & 08/01/98 \\
\hline & WF3 & Chlor & Cucumber & Jackson & 07/30/98 \\
\hline
\end{tabular}

\footnotetext{
${ }^{\text {a }}$ Fungicides applied: Chlor $=$ chlorothalonil, $\mathrm{Mz}=$ mancozeb, Oxy Chlor $=$ oxy chloride, Thio $=$ thiophanate methyl, Ben = benomyl, Met $=$ metalaxyl.
}

b Planting date shown as month/day/year. 
LF3, and WF2) and two (CF2 and EF1) totrichum orbiculare and D. bryoniae occurred in equal frequencies (EF2).

Colletotrichum orbiculare was the most prevalent pathogen on leaves collected in 1998 , occurring most frequently at 18 of the 24 field sites (DF1, EF1, EF2, EF3, GF1, GF2, GF3, LF1, LF2, NF1, NF2, WF3). D. bryoniae was the second most prevalent pathogen, occurring most frequently at six field sites (DF2, DF3, LF3, RF1, RF2, and WaF1).

Ecological associations. The null hypothesis of no association (i.e., independence) between pathogens was rejected for 3 of 8 pairs in 1996 (Table 2), 12 of 26 pairs in 1997 (Table 3), and 25 of 32 pairs in 1998 (Table 4), for a total of 40 of 66 pairs tested. All but one of these associations were negative. In all three cases in which independence was rejected in 1996, Colletotrichum orbiculare and D. bryoniae were negatively associated (EF1, SF1, and SF2; Table 2). Values for the OI ranged from 0.15 to 0.36 , suggesting weak to midstrength negative association between these pathogens (Table 2).

D. bryoniae was negatively associated with another pathogen in 10 of 12 pairwise comparisons in 1997 (CF2, EF2, EF3, EF3, EF3, LF1, LF2, LF3, WF2, and WF3; Table 3). Colletotrichum orbiculare and $D$. field sites, respectively. At one site, ColleNF3, RF3, WaF2, WaF3, WF1, WF2, and

bryoniae were negatively associated in 4 of these 12 pairs (CF2, EF2, EF3, and WF3). At most sites where D. bryoniae, $P$. cubensis, and Corynespora cassiicola were most prevalent and at half of the sites where Colletotrichum orbiculare or A. cucumerina was the most prevalent pathogen, there were no significant associations among pathogens in pairwise comparisons. In a single instance, the null hypothesis of no association between $A$. cucumerina and Corynespora cassiicola was rejected and a positive relationship was found (LF2). The OI of strength of association ranged from 0.08 to 0.44 , with most values around 0.25 , indicating that most associations were in mid-strength range. A value of 0.44 was attained for the negative association between A. cucumerina and D. bryoniae.

A negative association was found for 25 of the 32 pairwise comparisons in 1998 (Table 4). Colletotrichum orbiculare and D. bryoniae occurred in 17 of the 25 negative associations (DF1, DF3, EF1, EF2, GF2, GF3, LF1, NF2, NF3, RF1, RF2, RF3, WaF1, WaF2, WaF3, WF1, and WF3). Colletotrichum orbiculare and Corynespora cassiicola occurred in 3 of the 25 associations (LF1, LF2, and WF3). A. cucumerina and D. bryoniae (DF2, LF3), Corynespora cassiicola and D. bryoniae (LF3, WF3), and D. bryoniae and $P$. cubensis (DF2) all were negatively associated. No independent occurrences were

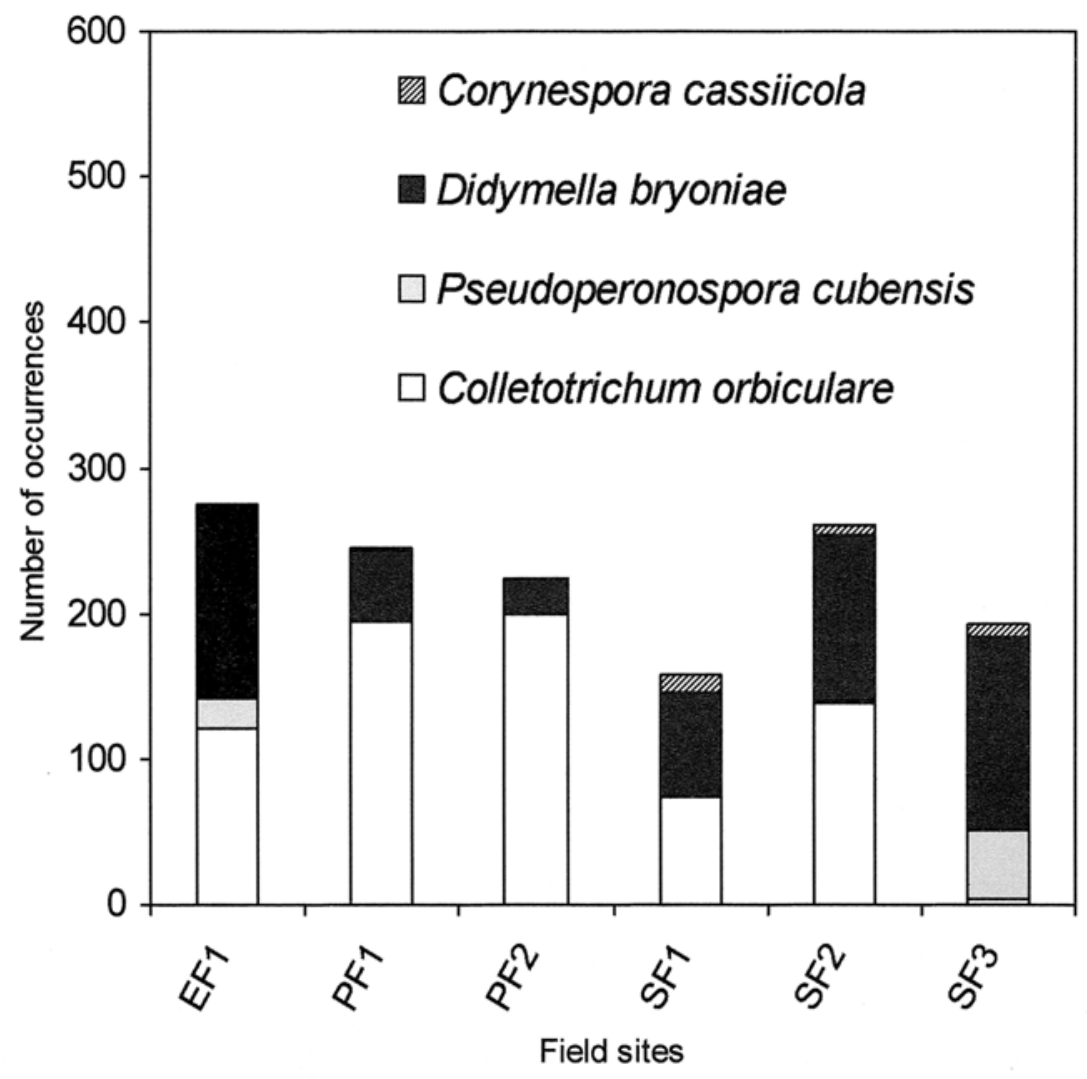

Fig. 1. Number of occurrences of cucumber leaf spot pathogens on symptomatic leaves collected from Edgecombe (EF1), Pitt (PF1 and PF2) and Sampson (SF1, SF2, and SF3) counties in North Carolina during 1996. found among pairs of pathogens identified in 1998 leaf samples. Values for OI in the range of 0.03 to 0.28 indicated that the negative pairwise associations ranged from weak for the association between Colletotrichum orbiculare and Corynespora cassiicola $(\mathrm{OI}=0.03)$ to mid-strength for the association between Colletotrichum orbiculare and D. bryoniae $(\mathrm{OI}=0.28)$.

Fungicide usage had no obvious effect on the spectrum of pathogens found or on the nature of the interaction among pathogens found together on a leaf (Table 5). Mainly protectant fungicides, such as chlorothalonil and mancozeb, and the systemic fungicide metalaxyl were used in the cucumber fields to control leaf spotting pathogens (Tables 1 and 5). The most frequently occurring pathogen association, Colletotrichum orbiculare with D. bryoniae, occurred on cucumber leaves independent of the type or combination of fungicide treatment applied to those fields where samples were collected. In addition, this specific pathogen association was the only combination found occurring on leaf samples collected from the four unsprayed fields in the test (97DF3, 98RF1, 98RF2, and 98RF3). The single positive association (A. cucumerina and Corynespora cassiicola) occurred on leaves collected from fields sprayed with chlorothalonil (97LF2). Sixteen negative associations, constituting four different pathogen combinations, were found on leaves collected from fields sprayed with chlorothalonil. No differences in the spectrum of pathogens or the combination of pathogen pairs were identified among leaves of the five different cucumber cultivars surveyed in this study.

\section{DISCUSSION}

Of the five pathogens identified on cucumber leaves in North Carolina, D. bryoniae and Colletotrichum orbiculare were the most prevalent. The interspecific associations between these two pathogens may imply spatial relationships (10). The negative associations between the two dominant pathogens imply that they each occupy a distinct niche in the cucumber canopy (10). This pattern may have resulted because each organism has distinct environmental and resource requirements or, perhaps, display competitive exclusion or antagonism. Pathogens that share specialized niche requirements often occur together and would primarily exhibit a positive association (10). Although the two dominant pathogens in this study require the presence of free moisture for infection and high relative humidity $(\mathrm{RH})$ for rapid disease progress $(2,6,14,16)$, long periods of free water are required for infection by $D$. bryoniae. Arny and Rowe (1) demonstrated that, within a favorable temperature range for infection by $D$. bryoniae, leaf wetness was the most important determinant. VanSteekelenberg (19) reported that infection of cucumbers by $D$. bryoniae occurred 


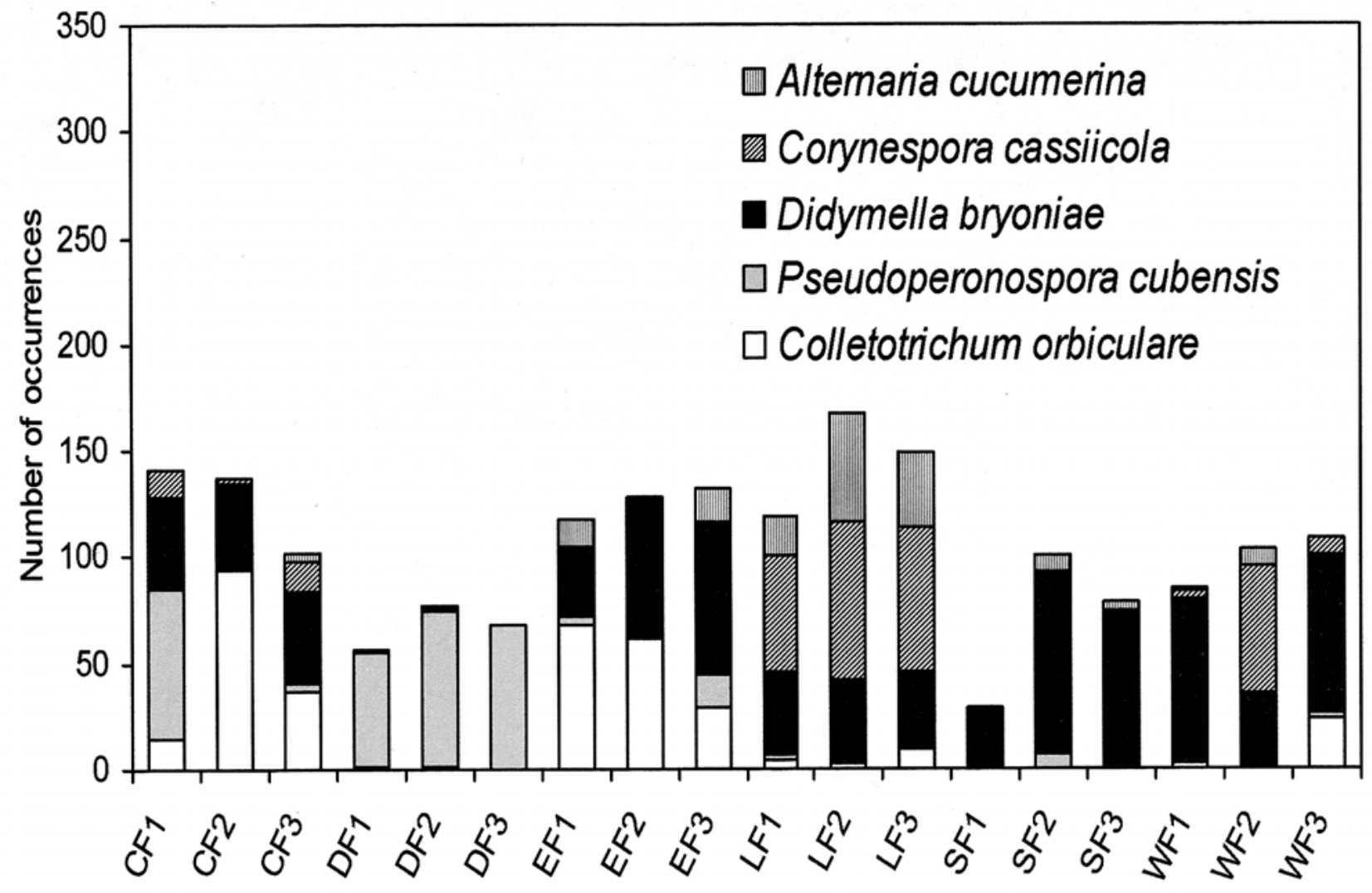

Field sites

Fig. 2. Number of occurrences of cucumber leaf spot pathogens on symptomatic leaves collected from Columbus (CF1, CF2, and CF3), Duplin (DF1, DF2, and DF3), Edgecombe (EF1, EF2, and EF3), Lenoir (LF1, LF2, and LF3), Sampson (SF1, SF2, and SF3), and Wayne (WF1, WF2, and WF3) counties in North Carolina during 1997.

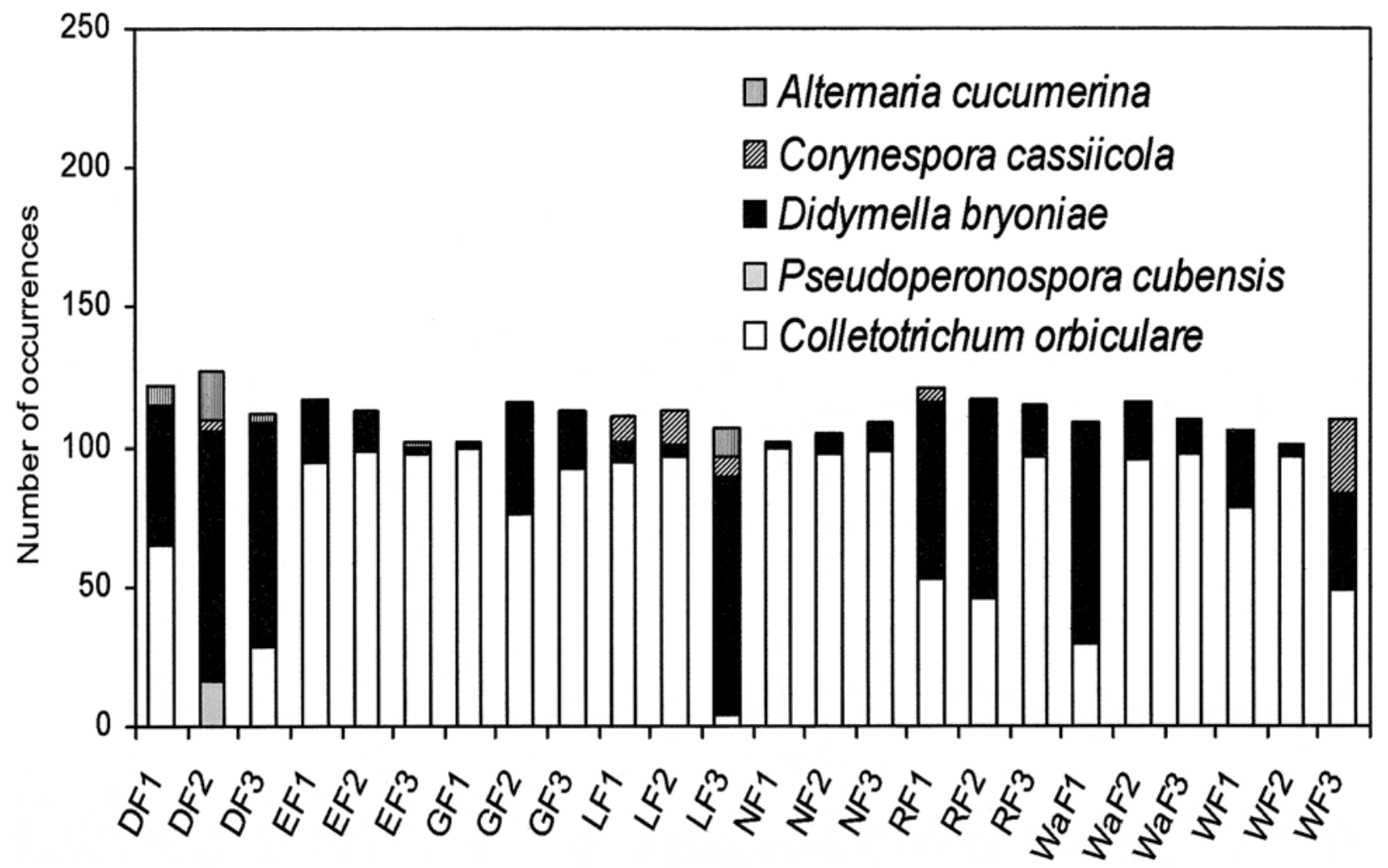

Fig. 3. Number of occurrences of cucumber leaf spot pathogens on symptomatic leaves collected from Duplin (DF1, DF2, and DF3), Edgecombe (EF1, EF2, and EF3), Greene (GF1, GF2, and GF3), Lenoir (LF1, LF2, and LF3), Nash (NF1, NF2, and NF3), Robeson (RF1, RF2, and RF3),Wayne (WaF1, WaF2, and WaF3), and Wilson (WF1, WF2, and WF3) counties in North Carolina during 1998. 
most rapidly at $95 \% \mathrm{RH}$ and was most severe when leaf surfaces were constantly wet. Therefore, $D$. bryoniae may be more suited to colonize tissue within the plant canopy where long periods of free water are available (C. L. Campbell, unpublished).
Disease development in Colletotrichum orbiculare also is influenced by the length of the wet period $(8,16)$, but Monroe et al. (9) demonstrated that, within the optimum temperature range for Colletotrichum orbiculare, $2 \mathrm{~h}$ of leaf wetness was sufficient for infection. In addition, the optimum temperature ranges for these two pathogens may limit the pathogens to their respective niches. Temperatures ranging from 20 to $32^{\circ} \mathrm{C}$ are favorable for infection and colonization of cucumber leaves by Colleto-

Table 2. Significant associations among pairs of pathogens observed on cucumber leaves exhibiting foliar disease symptoms in North Carolina in $1996^{\mathrm{a}}$

\begin{tabular}{llccc}
\hline Site & \multicolumn{1}{c}{ Pathogen pair } & $\chi^{\mathbf{2}}$ value & Type of association & Ochiai index $^{\mathbf{c}}$ \\
\hline EF1 & Colletotrichum orbiculare/Didymella bryoniae & 16.50 & Negative & 0.15 \\
SF1 & C. orbiculare/D. bryoniae & 22.32 & Negative & 0.36 \\
SF2 & C. orbiculare/D. bryoniae & 7.24 & Negative & 0.36 \\
\hline
\end{tabular}

a Significant associations occurring among pairs of pathogens together on a single leaf more than five times per set of 200 leaves

b The null hypothesis of no association between pathogens (i.e., independence) was rejected at $P>0.05$, if the calculated $\chi^{2}$ value for was greater than or equal to the critical value of 3.84 with 1 d.f.

${ }^{\mathrm{c}}$ Ochiai index $=a /\left[(a+b)^{0.5}(a+c)^{0.5}\right]$ where $a=$ the number of leaves where both species occurred, $b=$ the number of leaves where only species $X$ occurred, and $c=$ the number of leaves where only species $Y$ occurred.

Table 3. Significant associations among pairs of pathogens observed on cucumber leaves exhibiting foliar disease symptoms in North Carolina in $1997^{\text {a }}$

\begin{tabular}{llrcc}
\hline Site & \multicolumn{1}{c}{ Pathogen pair } & $\chi^{\mathbf{2}}$ value & Type of association & Ochiai index $^{\mathbf{b}}$ \\
\hline CF2 & Colletotrichum orbiculare/Didymella bryoniae & 9.19 & Negative & 0.19 \\
EF2 & C. orbiculare/D. bryoniae & 13.88 & Negative & 0.33 \\
EF3 & C. orbiculare/D. bryoniae & 8.33 & Negative & 0.24 \\
EF3 & D. bryoniae/Pseudoperonspora cubensis & 8.96 & Negative & 0.40 \\
EF3 & Alternaria cucumerina / D. bryoniae & 11.25 & Negative & 0.08 \\
LF1 & Corynespora cassiicola/D. bryoniae & 18.85 & Negative & 0.19 \\
LF2 & A. cucumerina/D. bryoniae & 11.93 & Negative & 0.20 \\
LF2 & A. cucumerina/C. cassiicola & 8.15 & Positive & 0.30 \\
LF3 & A. cucumerina / D. bryoniae & 6.68 & Negative & 0.44 \\
LF3 & A. cucumerina/C. cassiicola & 4.65 & Negative & 0.28 \\
WF2 & C. cassiicola /D. bryoniae & 26.37 & Negative & 0.24 \\
WF3 & Colletotrichum orbiculare/D. bryoniae & 6.46 & Negative & 0.23 \\
\hline
\end{tabular}

${ }^{a}$ Significant associations occurring among pairs of pathogens together on a single leaf more than five times per set of 100 leaves.

${ }^{\mathrm{b}}$ The null hypothesis of no association between pathogens (i.e., independence) was rejected at $P>0.05$, if the calculated $\chi^{2}$ value for was greater than or equal to the critical value of 3.84 with $1 \mathrm{df}$.

${ }^{c}$ Ochiai index $=a /\left[(a+b)^{0.5}(a+c)^{0.5}\right]$ where $a=$ the number of leaves where both species occurred, $b=$ the number of leaves where only species $X$ occurred, and $c=$ the number of leaves where only species $Y$ occurred.

Table 4. Significant associations among pairs of pathogens observed on cucumber leaves exhibiting foliar disease symptoms in North Carolina in $1998^{a}$

\begin{tabular}{|c|c|c|c|c|}
\hline Site & Pathogen pair & $\chi^{2}$ value & Type of association ${ }^{b}$ & Ochiai index ${ }^{c}$ \\
\hline DF1 & Colletotrichum orbiculare/Didymella bryoniae & 56.04 & Negative & 0.20 \\
\hline DF2 & D. bryoniae/Pseudoperonospora cubensis & 9.56 & Negative & 0.07 \\
\hline DF2 & Alternaria cucumerina/D. bryoniae & 4.17 & Negative & 0.23 \\
\hline DF3 & C. orbiculare/D. bryoniae & 51.82 & Negative & 0.17 \\
\hline EF1 & C. orbiculare/D. bryoniae & 18.66 & Negative & 0.26 \\
\hline EF2 & C. orbiculare/D. bryoniae & 6.20 & Negative & 0.24 \\
\hline GF2 & C. orbiculare/D. bryoniae & 49.39 & Negative & 0.21 \\
\hline GF3 & C. orbiculare/D. bryoniae & 32.71 & Negative & 0.06 \\
\hline LF1 & C. orbiculare D. bryoniae & 8.80 & Negative & 0.14 \\
\hline$L F 1$ & Colletotrichum orbiculare/Corynespora cassiicola & 6.18 & Negative & 0.17 \\
\hline LF2 & Colletotrichum orbiculare/Corynespora cassiicola & 22.68 & Negative & 0.19 \\
\hline LF3 & Corynespora cassiicola/D. bryoniae/ & 8.35 & Negative & 0.12 \\
\hline LF3 & Alternaria cucumerina/D. bryoniae & 36.82 & Negative & 0.06 \\
\hline NF2 & Colletotrichum orbiculare/D. bryoniae & 7.00 & Negative & 0.15 \\
\hline NF3 & C. orbiculare/D. bryoniae & 9.09 & Negative & 0.20 \\
\hline RF1 & C. orbiculare/D. bryoniae & 22.34 & Negative & 0.28 \\
\hline RF2 & C. orbiculare/D. bryoniae & 47.95 & Negative & 0.23 \\
\hline RF3 & C. orbiculare/D. bryoniae & 4.96 & Negative & 0.26 \\
\hline WaF1 & C. orbiculare/D. bryoniae & 56.64 & Negative & 0.16 \\
\hline $\mathrm{WaF} 2$ & C. orbiculare/D. bryoniae & 16.67 & Negative & 0.25 \\
\hline WaF3 & C. orbiculare/D. bryoniae & 14.97 & Negative & 0.20 \\
\hline WF1 & C. orbiculare/D. bryoniae & 47.66 & Negative & 0.16 \\
\hline WF3 & C. orbiculare/D. bryoniae & 16.64 & Negative & 0.15 \\
\hline WF3 & Colletotrichum orbiculare/Corynespora cassiicola & 30.37 & Negative & 0.03 \\
\hline WF3 & Corynespora cassiicola/D. bryoniae & 11.66 & Negative & 0.04 \\
\hline
\end{tabular}

${ }^{a}$ Significant associations occurring among pairs of pathogens together on a single leaf more than five times per set of 100 leaves.

${ }^{\mathrm{b}}$ The null hypothesis of no association between pathogens (i.e., independence) was rejected at $P>0.05$, if the calculated $\chi^{2}$ value for was greater than or equal to the critical value of 3.84 with $1 \mathrm{df}$.

${ }^{c}$ Ochiai index $=a /\left[(a+b)^{0.5}(a+c)^{0.5}\right]$ where $a=$ the number of leaves where both species occurred, $b=$ the number of leaves where only species $X$ occurred, and $c=$ the number of leaves where only species $Y$ occurred. 
trichum orbiculare $(5,8,9,16)$, while temperatures ranging from 24 to $27^{\circ} \mathrm{C}$ are favorable for infection and colonization by D. bryoniae $(1,15,19)$. In addition, although both pathogens can infect tissues of varying ages and stages of growth, $D$. bryoniae tends to infect older tissue and Colletotrichum orbiculare tends to infect younger tissues (3). Therefore, the specific growth requirements for each of these pathogens and the age of the leaf tissue they prefer to colonize may lead to the interspecific pattern observed in this study.

Different amounts of rainfall in each year of the study may have influenced the pathogen complex responsible for the leaf spot epidemics on cucumber. In 1996, conditions were wet and humid, which is favorable for infection and colonization by Colletotrichum orbiculare and D. bryoniae. Conditions in 1998 were dry early in the growing season (July), but became wet and favorable for infection by Colletotrichum orbiculare and D. bryoniae during August, when the crop was developing (Table 6). Conditions in 1997 were drier and less favorable for infection and colonization by the two dominant pathogens in this study. Hence, other leaf-spotting fungi such, as $P$. cubensis and Corynespora cassiicola, whose dispersal and infection are favored by drier conditions, were more frequently found associated with cucumber leaf spots in 1997.

Other factors, such as presence of inoculum and host resistance, may have influenced pathogen prevalence. The ubiquitous occurrence of Colletotrichum orbiculare and $D$. bryoniae relate directly to their ability to overwinter in crop debris and slowly build up during the first growing cycle when temperatures are cooler. In contrast, $P$. cubensis does not overwinter in cucumber fields in North Carolina, and reliance on windborne dissemination of spores causes the disease to occur sporadically (C. L. Campbell, unpublished).

None of the cultivars in this study are resistant to $D$. bryoniae or Corynespora cassiicola (3). Resistance to A. cucumerina has been identified in cucumber but presently is unavailable in commercially acceptable cultivars (3). All cultivars used in this study, except Vlasstar, contain moderate levels of resistance to Colletotrichum orbiculare as well as resistance to $P$. cubensis (3). In this study, environmental conditions were favorable for infection by D. bryoniae and Colletotrichum orbiculare. Although the cultivars grown were susceptible to A. cucumerina and Corynespora cassiicola, environmental conditions were less favorable for the development of these pathogens. Hence, these pathogens did not occur in high numbers on the leaf samples collected. Resistance to $P$. cuben-

Table 5. Significant pathogen associations and nature of association related to fungicide applications and cultivar in North Carolina cucumber sites from which leaves exhibiting foliar disease symptoms were collected in 1997 and 1998

\begin{tabular}{|c|c|c|c|c|}
\hline Year, site ${ }^{\mathrm{a}}$ & Fungicide $^{\mathrm{b}}$ & Associations $^{\mathrm{c}}$ & Cultivar & Pathogens \\
\hline \multicolumn{5}{|l|}{1997} \\
\hline CF2 & Met & $1 \mathrm{~N}$ & Jackson & Colletotrichum orbiculare/Didymella bryoniae \\
\hline $\mathrm{EF} 2$ & Chlor & $1 \mathrm{~N}$ & Vlaspik & C. orbiculare/D. bryoniae \\
\hline EF3 & Chlor & $3 \mathrm{~N}$ & Vlaspik & $\begin{array}{l}\text { C. orbiculare/D. bryoniae, D. bryoniae/Pseudoperonospora cubensis, } \\
\text { Alternaria cucumerina/D. bryoniae }\end{array}$ \\
\hline LF1 & Chlor & $1 \mathrm{~N}$ & Cross Country & C. orbiculare/D. bryoniae \\
\hline LF2 & Chlor & $2 \mathrm{~N}$ & Cross Country & A. cucumerinalD. bryoniae, A. cucumerina/Corynespora cassiicola \\
\hline LF3 & Chlor & $2 \mathrm{~N}$ & Cross Country & A. cucumerina/C. cassiicola, A. cucumerinalD. bryoniae \\
\hline WF2 & Other & $1 \mathrm{~N}$ & Cross Country & C. cassiicola/D. bryoniae \\
\hline WF3 & Other & $1 \mathrm{~N}$ & Cross Country & Colletotrichum orbiculare/D. bryoniae \\
\hline \multicolumn{5}{|r|}{ Conetortchum orotcutarets. oryomiae } \\
\hline RF1 & None & $1 \mathrm{~N}$ & Vlasstar & C. orbiculare/D. bryoniae \\
\hline RF2 & None & $1 \mathrm{~N}$ & Vlasstar & C. orbiculare/D. bryoniae \\
\hline RF3 & None & $1 \mathrm{~N}$ & Vlasstar & C. orbiculare/D. bryoniae \\
\hline $\mathrm{EF} 1$ & Chlor & $1 \mathrm{~N}$ & Vlaspik & C. orbiculare/D. bryoniae \\
\hline $\mathrm{EF} 2$ & Chlor & $1 \mathrm{~N}$ & Vlaspik & C. orbiculare/D. bryoniae \\
\hline GF2 & Chlor & $1 \mathrm{~N}$ & Jackson & C. orbiculare/D. bryoniae \\
\hline GF3 & Chlor & $1 \mathrm{~N}$ & Napolean & C. orbiculare/D. bryoniae \\
\hline LF1 & Chlor & $2 \mathrm{~N}$ & Cross Country & C. orbiculare/D. bryoniae, Colletotrichum orbiculare/Corynespora cassiicola \\
\hline LF2 & Chlor & $1 \mathrm{~N}$ & Cross Country & Colletotrichum orbiculare/Corynespora cassiicola \\
\hline LF3 & Chlor & $2 \mathrm{~N}$ & Cross Country & A. cucumerina/D. bryoniae, Corynespora cassiicolalD. bryoniae \\
\hline NF2 & Chlor & $1 \mathrm{~N}$ & Vlaspik & Colletotrichum orbiculare/D. bryoniae \\
\hline NF3 & Chlor & $1 \mathrm{~N}$ & Vlaspik & C. orbiculare/D. bryoniae \\
\hline WF1 & Chlor & $1 \mathrm{~N}$ & Napolean & C. orbiculare/D. bryoniae \\
\hline WF3 & Chlor & $3 \mathrm{~N}$ & Jackson & $\begin{array}{l}\text { C. orbiculare/D. bryoniae, Colletotrichum orbiculare/Corynespora cassiicola, } \\
\text { Corynespora cassiicolalD. bryoniae }\end{array}$ \\
\hline DF1 & Chlor + other & $1 \mathrm{~N}$ & Vlasstar & Colletotrichum orbiculare/D. bryoniae \\
\hline DF2 & Chlor + other & $2 \mathrm{~N}$ & Vlasstar & D. bryoniae/P. cubensis, A. cucumerina/D. bryoniae \\
\hline DF3 & Chlor + other & $1 \mathrm{~N}$ & Vlasstar & C. orbiculare/D. bryoniae \\
\hline WaF1 & Other & $1 \mathrm{~N}$ & Vlasstar & C. orbiculare/D. bryoniae \\
\hline $\mathrm{WaF} 2$ & Other & $1 \mathrm{~N}$ & Vlasstar & C. orbiculare/D. bryoniae \\
\hline $\mathrm{WaF} 3$ & Other & $1 \mathrm{~N}$ & Vlasstar & C. orbiculare/D. bryoniae \\
\hline
\end{tabular}

a Data on fungicide applications and cultivars for 1996 unavailable.

${ }^{\mathrm{b}}$ Fungicides applied: Chlor $=$ chlorothalonil, Met $=$ metalaxyl, Other $=$ other protectants

${ }^{c}$ Pathogen associations: $\mathrm{N}=$ negative, $\mathrm{P}=$ positive, number preceding $=$ number of significant associations

Table 6. Mean monthly temperatures and precipitation in eastern North Carolina cucumber growing region (Clinton NE weather station) in August, September, and October 1996, 1997, and 1998

\begin{tabular}{|c|c|c|c|c|c|c|c|}
\hline \multirow[b]{2}{*}{ Year } & \multicolumn{3}{|c|}{ Mean temperature $\left({ }^{\circ} \mathrm{C}\right)$} & \multicolumn{4}{|c|}{ Mean precipitation $(\mathrm{cm})$} \\
\hline & August & September & October & August & September & October & Total \\
\hline 1996 & 23.2 & 20.9 & 15.8 & 8.9 & 35.3 & 14.8 & 59.0 \\
\hline 1997 & 23.3 & 21.2 & 15.9 & 8.9 & 18.5 & 9.5 & 36.9 \\
\hline 1998 & 24.4 & 22.7 & 16.4 & 20.3 & 9.04 & 1.7 & 31.0 \\
\hline
\end{tabular}

${ }^{a}$ Data from United States Department of Commerce National Oceanic and Atmospheric Administration annual climatological summary. 
sis in each of the cultivars in this study may have limited the number of occurrences of this pathogen. The dominant pathogen combination (Colletotrichum orbiculare and $D$. bryoniae) was identified on all five cultivars in the study and other pathogen combinations also were observed on different cultivars.

A range of systemic and protectant fungicides were used to control leaf spot fungi in the field sites in this study. Although no data were recorded on the frequency and dosage of fungicide applications, no specific relationship between the fungicides used in each field site and the pathogens observed on leaves sampled from different sites was found. In addition, various pathogen combinations were identified on leaves collected from field sites managed under different fungicide spray programs, and the dominant pathogen combination was identified on leaves from field sites sprayed with each fungicide type.

Environmental conditions in cucumber fields in North Carolina are favorable for the growth and reproduction of many different foliar pathogens (4). Identifying the major pathogens in cucumber fields in North Carolina and the relative importance of each could facilitate better management of the causal organisms involved in leaf spot epidemics and be used to target breeding and research on disease control measures towards these pathogens.

\section{ACKNOWLEDGMENTS}

P. D. Peterson thanks T. Sutton, G. Holmes, and B. Shew for their comments on earlier drafts of the manuscript; D. Fraser for assistance with statistical analyses and preparation of the manuscript for publication; and $\mathrm{L}$. Campbell, whose steady guidance, unwavering patience, and open office door made him the best kind of teacher.

\section{LITERATURE CITED}

1. Arny, C. J., and Rowe, R. C. 1991. Effects of temperature and duration of surface wetness on spore production and infection of cucumbers by Didymella bryoniae. Phytopathology 81:206-209.

2. Chiu, W. F., and Walker, J.C. 1949. Physiology and pathogenicity of the cucurbit blackrot fungus. J. Agric. Res. 78:589-615.

3. Gouker, P. E., Wehner, T. C., and Harvey, M. J. 2000. Cucumber disease handbook. North Carolina State University, Raleigh.

4. Hughes, G. R., Averre, C. W., and Sorensen, K. A. 1990. Growing Pickling Cucumbers in North Carolina. North Carolina Extension Service, Raleigh.

5. Ishida, N., and Akai, S. 1969. Relation of temperature to germination of conidia and appressorium formation in Colletotrichum lagenarium. Mycologia 61:382-386.

6. Litterell, R. H., and Epps, W. M. 1965. Standardization of a procedure for artificial inoculation of cucumbers with Colletotrichum lagenarium. Plant Dis. Rep. 49:649-653.

7. Luepschen, N. S. 1961. The development of the Mycosphaerella black rot and Pellicularia rolfsii rot of watermelon at various temperatures. Plant Dis. Rep. 45:557-559.

8. McRae, C. F., and Auld, B. A. 1988. The influence of environmental factors on the anthracnose of Xanthium spinosum. Phytopathology 78:1182-1186

9. Monroe, J. S., Santini, J. B., and Latin, R. 1997. A model defining the relationship between temperature and leaf wetness duration, and infection of watermelon by Colletotrichum orbiculare. Plant Dis. 81:739-742.
10. Nelson, S. C., and Campbell, C. L. 1992 Incidence and patterns of association of pathogens in a leaf spot disease complex on white clover in the Piedmont region of North Carolina. Phytopathology 82:10131021.

11. Ochiai, A. 1957. Zoogeographic studies on the soleoid fishes found in Japan and its neighbouring regions. Bull. Jpn. Soc. Sci. Fish. 22:526-530.

12. Pielou, E. C. 1977. Mathematical Ecology. Wiley, New York

13. Sitterly, W. R. 1973. Breeding for disease resistance in cucurbits. Annu. Rev. Phytopathol. 10:471-490.

14. St. Amand, P. C., and Wehner, T. C. 1995. Greenhouse, detached-leaf, and field testing methods, determine cucumber resistance to gummy stem blight. J. Am. Soc. Hortic. Sci. 120 (4):673-680

15. Svedelius, G., and Unestam, T. 1978. Experimental factors favoring infection of attached cucumber leaves by Didymella bryoniae. Trans. Br. Mycol. Soc. 71:89-97.

16. Thompson, D. C., and Jenkins, S. F. 1985 Effect of temperature, moisture, and cucumber cultivar resistance on lesion size increase and conidial production by Colletotrichum lagenarium. Phytopathology 75:828-832.

17. Thompson, D. C., and Jenkins, S. F. 1985. Influence of cultivar resistance, environment, and fungicide concentration and timing of application on anthracnose development and yield loss in pickling cucumbers. Phytopathology 75:1422-1427.

18. Toth, S. J., Averre, C. W., Monks, D. W., Schultheis, J. R., and Sorensen, K. A. 1990 Cucumber pest management. North Carolina State University Extension Service, North Carolina State University, Raleigh.

19. VanSteekelenburg, N. A. M. 1982. Factors influencing external fruit rot of cucumber caused by Didymella bryoniae. Neth. J. Plant Pathol. 88:47-56. 